\title{
塑性流動における速度場の理論
}

\author{
正員山口柏樹*
}

\section{A THEORY ON THE VELOCITY FIELD IN THE PLASTIC FLOW OF GRANULAR MATERIALS}

\author{
By Hakuju Yamaguchi, C.E. Member
}

Synopsis : In the present paper, the general theory on the velocity field in the plastic flow of granular materials with frictional resistance has been discussed. The developed formula of Geiringer's equation and the compressibility law in the flow state can be introduced by making the two characteristic lines with respect to both velocity and stress conincide. By the conception of plastic potential the relations between stress and strain increment in two and three dimensional state and the yield condition are also presented. The former relations are known to be same to Lévy-Mises ones. In case where the angle of internal friction is not so large, the above yield condition and newly introduced Poisson's ratio are shown fairly agree with the corresponding expressions already given by Prof. Hoshino. The deduced dilatancy formula in the shearing flow is checked up experimentally.

要 旨 本論文では摩擦を有する粒状物質の塑性流動に拮ける速度場の一般論につさ述べる。速度と 応力の特性曲線を一致せしめることとより Geiringer の拡張式が得られ，流動時の可圧表式があわせ導 かれた。塑性ポテンシアルの概念により二，三次元の応力とひずみ増分関係式执よび降伏条件式を誘導 したが前者は Lévy-Mises 式と恒同であることが判つた。あまり過大でない内部摩擦角の場合，三次元 降伏条件式と流動時のポアソン比は星埜教授の塑性論に和汀る式とよく一致する。な和本理論を適用し て流動時のダイレイタンシー式を導き，実験的にも妥当であることが認められた。

\section{1. 問題の展望}

金首塑性理論では等方性と 非可圧性の仮定が妥当であると認められているから，完全塑性体の平面ひずみ問題 では Geiringer の速度式が導かれ，不静定問題の理論的取扱いが可能とされている。この場合す速度方程式は応

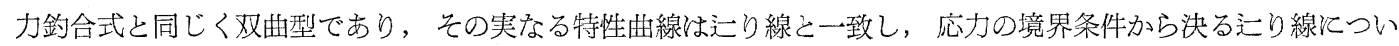
て，速度式を積分し境界で与兄られる速度条件を吟味することができる。さらに，ひずる速度内と降伏曲線が相似 形で，かつ相似の位置にあることから，ひずみ速度（またはひずみ増分）と偏差応力の比例関係 (Mises の式) 子容易燇き出される。他方, 摩擦を有する塑性体飞执いては, 後述のごとく等方性と非可圧性を固執する限り, 応力と速度の特性曲線は一致しない。Hil1 ${ }^{11}$ とよれば解の一意性の見地から雨特性曲線の一致怔必要条件の一つと 思われる。物理的にみても, 静止せる塑性域と, 流動する塑性域の境界は応力勾配や速度勾配飞関して不連続的 な線であるから, 応力の特性曲線が速度の特性曲線ともなることは必然的要求と考光られる。

本論文では，前段飞括いてまず上述の一致条件を満をす速度方程式を求め，それよりひずみ増分と応力の関係 を導いたが，これらの議論は完全塑性体としてのみ成り立つこと，換言すれば降伏応力を過ぎて塑性流動が始ま る以後の現象にのみ適用されるものであることを銘記せねね゙ならない。るちろん一致せしめる方法は唯一である 必要はないから，異なる方法で異なる形の速度方程式や，応力一ひずみ増分の関係式多得られるであろう。これ らの正否は実験や他理論との照合にまつべきであるから，応力一ひずみ増分の関係から 演訳した理諭的な三次元 降伏条件式と星埜教授の降伏条件との対比を調べ，さらにダイレイタンシーの公式を誘導し 実験結果を説明し得 るか不かを検討した。本論と入る前順序として，摩擦性塑性体の流動時飞括ける速度方程式が，等方，非可圧 の仮定に対してはどうなるか調べてみよう。

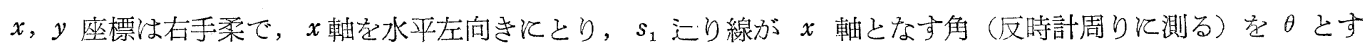
る。変位速度成分を $u_{x}, u_{y}$ とするとひずみ速度成分は

* 中央大学助教授, 工学部土木工学科 


$$
\dot{\varepsilon}_{x}=\partial u_{x} / \partial x \quad \dot{\varepsilon}_{y}=\partial u_{y} / \partial y \quad \dot{r}_{x y}=\frac{1}{2}\left(\partial u_{x} / \partial y+\partial u_{y} / \partial x\right)
$$

で定義される。非可圧条件は

$$
\dot{\varepsilon}_{x}+\dot{\varepsilon}_{y}=\partial u_{x} / \partial x+\partial u_{y} / \partial y=0
$$

等方性条件は内部摩擦角を $\dot{\phi}$ として

$$
\partial u_{x} / \partial y+\partial u_{y} / \partial x=\cot (2 \theta-\phi)\left(\partial u_{y} / \partial y-\partial u_{x} / \partial x\right)
$$

(1.3) 式は次のごとくして導かれる。大きい主応力 $\sigma_{1}$ が $x$ 軸となす角 $\alpha$ は $(\pi / 4-\phi / 2+\theta)$ であるから, $\sigma_{1}, \sigma_{2}$ が $x, y$ 軸となす角の方向余弦は

であり,これを等方性条件

$$
l_{1 x}=\cos \alpha, \quad l_{1 y}=\sin \alpha ; \quad l_{2 x}=-\sin \alpha \quad l_{2 y}=\cos \alpha
$$

水代大すると (1.3) 式が求まる。

(1.2)，(1.3) 式は $u_{x}, u_{x}$ 亿関して双曲型であるが, その特性曲線は最大せ九断灾力線注かならない。事実 直交する最大せん断応力線方向を $\lambda_{1}, \lambda_{2}$ とし, その方向の速度成分を $v_{1}, v_{2}$ とすると

$$
u_{x}=v_{1} \cos (\theta-\phi / 2)-v_{2} \sin (\theta-\phi / 2), \quad u_{y}=v_{1} \sin (\theta-\phi / 2)+v_{2} \cos (\theta-\phi / 2)
$$

であるから, 変換式

$$
\left.\partial / \partial x=\cos (\theta-\phi / 2) \partial / \partial \lambda_{1}-\sin (\theta-\phi / 2) \partial / \partial \lambda_{2}, \quad \partial / \partial y=\sin (\theta-\phi / 2) \partial / \partial \lambda_{1}+\cos \theta-\phi / 2\right) \partial / \partial \lambda_{2}
$$

《よつて, (1.2), (1.3) 式は $\partial v_{1} / \partial \lambda_{1}-v_{2} \partial \theta / \partial \lambda_{1}+\partial v_{2} / \partial \lambda_{2}+v_{1} \partial \theta / \partial \lambda_{2}=0$

$$
\begin{aligned}
\partial v_{1} / \partial \lambda_{1}-v_{2} \partial \theta / \partial \lambda_{1}-\partial v_{2} / \partial \lambda_{2}-v_{1} \partial \theta / \partial \lambda_{2} & =0 \\
\therefore \quad \frac{d v_{1}}{d \lambda_{1}}-v_{2} \frac{d \theta}{d \lambda_{1}}=0 \quad \frac{d v_{2}}{d \lambda_{2}}+v_{1} \frac{d \theta}{d \lambda_{2}} & =0
\end{aligned}
$$

が最大せて断応力線方向, $\lambda_{1}, \lambda_{2}$ 亿対して行われる。これはいわゆる Geiringer の式であるが, 同時にこの方向 が速度の特性曲線なることを示している。

他方, 応力特性曲線（迄り線）成分飞関して (1.2)，(1.3) 式を変換すると

$$
\left.\begin{array}{l}
\cos \phi \frac{\partial u_{1}}{\partial s_{1}}-u_{1} \sin \phi \frac{\partial \theta}{\partial s_{1}}-u_{2} \frac{\partial \theta}{\partial s_{1}}+\cos \phi \frac{\partial u_{2}}{\partial s_{2}}+u_{2} \sin \phi \frac{\partial \theta}{\partial s_{2}}+u_{1} \frac{\partial \theta}{\partial s_{2}}=0 \\
\frac{\partial u_{1}}{\partial s_{1}}+\sin \phi \frac{\partial u_{2}}{\partial s_{1}}-u_{2} \cos \phi \frac{\partial \theta}{\partial s_{1}}-\frac{\partial u_{2}}{\partial s_{2}}-\sin \phi \frac{\partial u_{1}}{\partial s_{2}}-u_{1} \cos \phi \frac{\partial \theta}{\partial s_{2}}=0
\end{array}\right\}
$$

が得られる。ここに $u_{1}, u_{2}$ は迄り線方向の速度成分で

$$
u_{x}=u_{1} \cos \theta-u_{2} \sin (\theta-\phi), u_{y}=u_{1} \sin \theta+u_{2} \cos (\theta-\phi)
$$

飞より $u_{x}, u_{x}$ と結ばれる。な括との際の微分変換式は

$$
\frac{\partial}{\partial x}=\frac{1}{\cos \phi}\left\{\cos (\theta-\phi) \frac{\partial}{\partial s_{1}}-\sin \theta \frac{\partial}{\partial s_{2}}\right\}, \frac{\partial}{\partial y}=\frac{1}{\cos \phi}\left\{\sin (\theta-\phi) \frac{\partial}{\partial s_{1}}+\cos \theta \frac{\partial}{\partial s_{2}}\right\}
$$

を用いてある。(1.5) 式でみられる通り, 等方, 非可圧の仮定の下では过り線関する速度成分が簡単な形で表わ されないし，もちろえ差分的数值解法の適用もできない。

等方, 非可圧とした時の速度方程式の特性曲線が, 主応力方向を二等分する最大せ九断応力線方向となり, 过

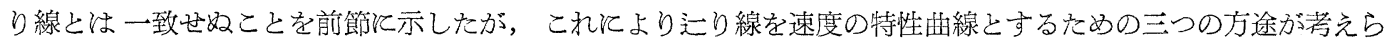
れる。すなわち i）非可圧性のみを放䢂して等方, 可圧性とすること, ii）等方性のみを放寨して非可圧, 異方性 とすること，iii）最す一般的化可圧，異方性とすること，等である。

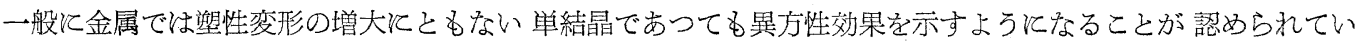

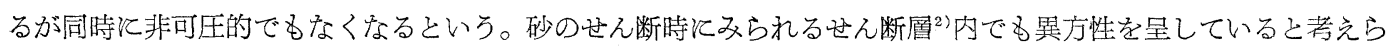
れる面がある。また自然の成層土が異方性であることる疑う余地はない。このように異方性を取り入れること法，

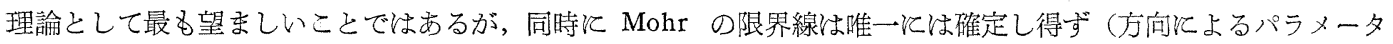

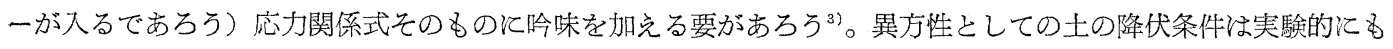
まだ十分研究されていない実情であるので ii)， iii）飞対する考察は今後の問題として残されるね゙ならない。

本論文では等方性は許されるとして（従つて搪張された Kötter 式などは使用できる）塑性材料が可圧性である 場合を考克ることとする。可圧性の式は未知であるが逆解法により以下のごとく求められる。(1.5) 式の下段の式 恃等方性なる (1.3) 式の変換であるから今の場合す成り立つものである。その式でさらに

$$
\frac{\partial u_{1}}{\partial s_{1}}+\sin \phi \frac{\partial u_{2}}{\partial s_{1}}-u_{2} \cos \phi \frac{\partial \theta}{\partial s_{1}}=0, \quad \frac{\partial u_{2}}{\partial s_{2}}+\sin \phi \frac{\partial u_{1}}{\partial s_{2}}+u_{1} \cos \phi \frac{\partial \theta}{\partial s_{2}}=0
$$

が成り立つと仮定しよう。上式で $\partial / \partial s_{i}$ は $d / d s_{i}$ と記してよいが，これはいうまでもなく方り線が速度の特性曲 
と一致することを意味している。(2.1) 式を再び直交成分に関し変換すれば（1.2）式に対応して可圧性表示式か5 得られよう。すなわち，

$$
\begin{aligned}
& u_{1}=\frac{1}{\cos \phi}\left\{u_{x} \cos (\theta-\phi)+u_{y} \sin (\theta-\phi)\right\}, u_{2}=\frac{1}{\cos \phi}\left(-u_{x} \sin \theta+u_{y} \cos \theta\right) \\
& \frac{\partial}{\partial s_{1}}=\cos \theta \frac{\partial}{\partial x}+\sin \theta \frac{\partial}{\partial y}, \frac{\partial}{\partial s_{2}}=-\sin (\theta-\phi) \frac{\partial}{\partial x}+\cos (\theta-\phi) \frac{\partial}{\partial y}
\end{aligned}
$$

そよつて (2.1) 式を改めると

$$
\begin{aligned}
& \cos \phi\left\{\frac{\partial u_{x}}{\partial x} \cos ^{2} \theta+\frac{\partial u_{y}}{\partial y} \sin ^{2} \theta+\left(\frac{\partial u_{x}}{\partial y}+\frac{\partial u_{y}}{\partial x}\right) \cos \theta \sin \theta\right\}=0 \\
& \cos \phi\left\{\frac{\partial u_{x}}{\partial x} \sin ^{2}(\theta-\phi)+\frac{\partial u_{y}}{\partial y} \cos ^{2}(\theta-\phi)-\left(\frac{\partial u_{x}}{\partial y}+\frac{\partial u_{y}}{\partial x}\right) \sin (\theta-\phi) \cos (\theta-\phi)\right\}=0
\end{aligned}
$$

こ礼老解いて (1.1) 式の記易を用いると

$$
\begin{gathered}
\dot{\varepsilon}_{x}=\frac{-2 \sin \theta \cos (\theta-\phi)}{\cos (2 \theta-\phi)} \dot{\gamma}_{x y}, \quad \dot{\varepsilon}_{y}=\frac{2 \cos \theta \sin (\theta-\phi)}{\cos (2 \theta-\phi)} \dot{\gamma}_{x y} \\
\therefore \dot{\varepsilon}_{x}+\dot{\varepsilon}_{y} \equiv 2 \dot{e}=\frac{-2 \sin \phi}{\cos (2 \theta-\phi)} \dot{\gamma}_{x y} \quad \ldots \ldots \ldots \ldots \ldots \ldots \ldots \ldots \ldots \ldots \ldots \ldots \ldots
\end{gathered}
$$

が得られる。(2.3) 式は (1.2) 式机対応した可圧性を表わす式で所求のものである。当然であるが (2.2) 式より

$$
\dot{\varepsilon}_{y}-\dot{\varepsilon}_{x}=2 \dot{r}_{x y} \tan (2 \theta-\phi)
$$

なる等方性の式 [(1.3)] が得られる。すなわち, 逆机等方的である摩擦性塑性材料では (2.3) 式で示される可圧 性を有する時, 速度と応力の特性曲線はいずれも过り線と一致し过り線関する速度方程式は (2.1) 式または

$$
\left.\begin{array}{l}
s_{1} \text { 飞沿つて }: d u_{1}+\sin \phi d u_{2}-u_{2} \cos \phi d \theta=0 \\
s_{2} \text { 飞沿つて }: d u_{2}+\sin \phi d u_{1}+u_{1} \cos \phi d \theta=0
\end{array}\right\}
$$

で与克られることとなる(証明は簡単だから省略す る)。 $\phi=0$ であれば (2.1) 式が Geiringer の式㴆 着することはいうまでもない。

(2.1) 式末たは (2.1') 式の幾何学的意味は过り線 沿う抻び速度が０であることである。何者 図一1 (a) とついて汇り線沿沿微小長 $d s_{1}$ の伸び速度が

$$
\begin{aligned}
& \left(u_{1}+d u_{1}\right) \cos d \theta+\left(u_{2}+d u_{2}\right) \sin (\phi-d \theta) \\
& -\left(u_{1}+u_{2} \sin \phi\right)
\end{aligned}
$$

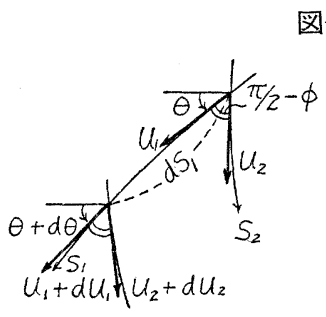

(a)

\section{図-1}

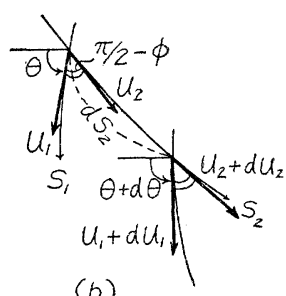

$$
=d u_{1}+\sin \phi d u_{2}-u_{2} \cos \phi d \theta+0\left(\varepsilon^{2}\right)
$$

であるから上のことは明らかである ( $s_{2}$ てついても同様)。すなわち $s_{1}, s_{2}$ 方向の伸びひずみ速度を $\dot{\varepsilon}_{S_{1}}$, $\dot{\varepsilon}_{S_{2}}$ と する上，これらは０となる(これは（2.2）式からも容易に得られることである)。また (2.1') 式から知れるよ う飞, $s_{i}$ が流線 $\left(s_{i}\right.$ 上で $\left.u_{j} \equiv 0\right)$ であれば $s_{i}$ 飞沿う速度は一定 $\left(d u_{i} \equiv 0\right)$ である。圧縮応力を正と約束する立 場では，压縮ひずみ増分を正と決めるのが便利であるが，このためには速度に負号をつければよい。こうしても 上の諸式はすべて速度成分の一次結合であるから式の形はなんら変更されることはない。

今まで暗に $\cos (2 \theta-\phi) \neq 0$ 蛋仮定して来たが, Rankine 过り線場では $\theta=\pi / 4+\phi / 2$ (主働)， $-\pi / 4+\phi / 2$ (受㗢)

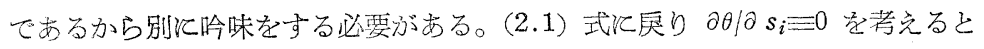

$$
\partial u_{1} / \partial s_{1}+\sin \phi \partial u_{2} / \partial s_{1}=0, \quad \partial u_{2} / \partial s_{2}+\sin \phi \partial u_{1} / \partial s_{2}=0
$$

が成立つから $x y$ 成分飞変換した結果

$$
\left.\begin{array}{ll}
\dot{\varepsilon}_{1}+\dot{\varepsilon}_{2}=\sin \phi\left(\dot{\varepsilon}_{1}-\dot{\varepsilon}_{2}\right) & \text { (主働時) } \\
\dot{\varepsilon}_{1}+\dot{\varepsilon}_{2}=\sin \phi\left(\dot{\varepsilon}_{2}-\dot{\varepsilon}_{1}\right) \quad \text { (受働時) }
\end{array}\right\}
$$

が容易汇求まる。ただし，乙の時 (1.3) 式から $\dot{r}_{x y}=0$ であるので, $\partial u_{x} / \partial x=\dot{\varepsilon}_{1}, \partial u_{y} / \partial y=\dot{\varepsilon}_{2}$ としてある。主 働の場合は $\dot{\varepsilon}_{2}>0$ (圧縮) と考㝋るべきであるが，これは $2 \dot{e}=\dot{\varepsilon}_{1}+\dot{\varepsilon}_{2}<0$ (壀脹) を意味する。何者 $0<\sin \phi<1$

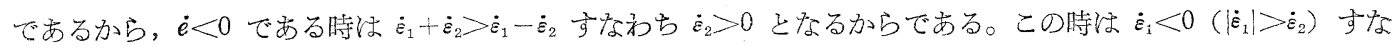
为台水平方向への膨镺がともなう。受衝の場合も $\dot{e}<0$ であるが $\dot{\varepsilon}_{1}>0, \dot{\varepsilon}_{2}<0,\left|\dot{\varepsilon}_{2}\right|>\dot{\varepsilon}_{1}$ となり水平方向压縮され る。(2.5) 式沾着力のない場合の降伏条件 $\sigma_{1}-\sigma_{2}=\sin \phi\left(\sigma_{2}+\sigma_{2}\right)$ 飞刘応与る。

塑性流動の生じている領域と静止している領域の境界を通じて速度が極限的に連続であるとすれば，年の境界

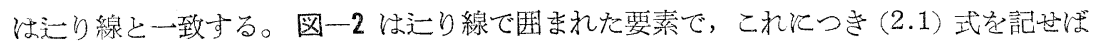




$$
\begin{aligned}
& u_{1} A-u_{1}^{B}+\sin \phi\left(u_{2}^{B}-u_{2}^{A}\right)-\frac{1}{2}\left(u_{2}^{B}+u_{2}^{A}\right)\left(\theta_{B}-\theta_{A}\right)=0 \\
& \left.u_{2} D-u_{2} A+\sin \phi\left(u_{1}^{D}-u_{1}^{A}\right)+\frac{1}{2}\left(u_{1}^{D}+u_{1}^{A}\right)\left(\theta_{D}-\theta_{A}\right)=0 \quad \text { ii }\right) \\
& \left.u_{1} C-u_{1} D+\sin \phi\left(u_{2} C-u_{2} D\right)-\frac{1}{2}\left(u_{2} C+u_{2} D\right)\left(\theta C-\theta^{D}\right)=0 \quad \text { iii }\right) \\
& \left.u_{2} C-u_{2}^{B}+\sin \phi\left(u_{1}^{C}-u_{1}^{B}\right)+\frac{1}{2}\left(u_{1}^{C}+u_{1}^{B}\right)\left(\theta_{C}-\theta_{B}\right)=0 \text { iv }\right)
\end{aligned}
$$

今过り線と一致せぬ線(例えば図一2で BD を結ぶ線のごときもの)が前述の 境界であるとし，BD の右上が静止域,左下が流動域と考える。速度が極限的飞連 続であるとすると $\mathrm{BD}$ 上で速度は0であるから $u_{1}{ }^{B}, u_{2}{ }^{B}, u_{1}{ }^{D}, u_{2}{ }^{D} \equiv 0$ として

\section{図-2}

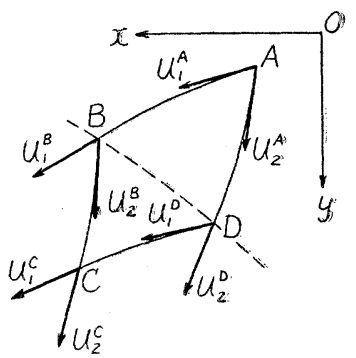

iii), iv) は $\quad \mathrm{u}_{1} C+\mathrm{u}_{2} C\left\{\sin \phi-\frac{1}{2}\left(\theta_{C}-\theta_{D}\right)\right\}=0, \quad \mathrm{u}_{2} C+\mathrm{u}_{1} C\left\{\sin \phi+\frac{1}{2}\left(\theta_{C}-\theta_{B}\right)\right\}=0$

上の二式で $u_{1}{ }^{c}, u_{2}{ }^{c}$ の係数の行列式は 0 でないから， $u_{1} c ， u_{2}{ }^{c}$ 恒等的飞 0 となり, BD の左下子静止 域となる。すなわち BD のような汇り線と一致しない線は境界とはなり得ない。一方沪り線 (例兄ば AB) が境

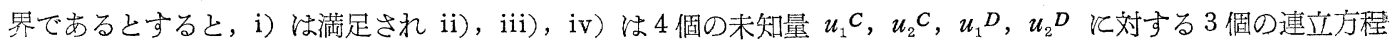
式だから $u$ は特別の制限を受けることなく0でない值をとり得て，AB の下方が流動域となり得る。これは, 过

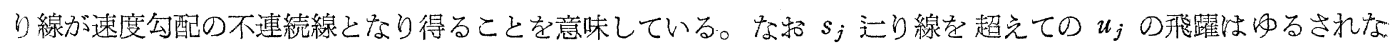
い。これは $\partial u_{j} / \partial s_{i}(i \neq j)=\infty$ であるが $\phi=0$ ならざる限り (2.1) 式から矛盾である。したがつて五り線を越 觉てその方向の速度分布が不連続的飞変化し得ぬが，これは金属の場合と大きな相違である。

\section{(例) 対数螺旋域での速度解 ${ }^{4}$}

放射動径を $s_{1}$, 対数螺旋を $s_{2}$ 芒り線とした時 $d s_{1}=d r, d s_{2}=r d \theta / \cos \phi$ であるので (2.1) 式な

$$
\begin{gathered}
\partial u_{1} / \partial r+\sin \phi \partial u_{2} / \partial r=0 \\
\partial u_{2} / \partial \theta+\sin \phi \partial u_{1} / \partial \theta+u_{1} \cos \phi=0 \\
\therefore \text { i) より } \quad u_{1}+u_{2} \sin \phi=f(\theta)
\end{gathered}
$$

iii）の左辺は $r$ に関せず，これより $\dot{\varepsilon}_{r}=0$ である。iii） ii）へ入れて積分すれば

$$
u_{1}=f(\theta)+\sin \phi e^{\mu \theta} \int_{\theta_{0}}^{\theta} e^{-\mu \theta} \frac{f \cos \phi+f^{\prime} \sin \phi}{\cos ^{2} \phi} d \theta-\sin \phi g(r) e^{\mu \theta}
$$

を得る。ここに $\mu=\tan \phi, f^{\prime}=d f / d \theta$ で $\theta_{0}$ 㥒螺旋の始動径の偏角である。iv）を iii）飞入れて

$$
u_{2}=e^{\mu \theta} \int_{\theta_{0}}^{\theta} e^{-\mu \theta} \frac{f \cos \phi+f^{\prime} \sin \phi}{\cos ^{2} \phi} d \theta+g(r) e^{\mu \theta}
$$

$f(\theta), g(r)$ は次のごとくして決める。今中心 $(\boldsymbol{r}=0)$ が塑性域内にあるとして, そこでの変位速度を $v_{0}$, 方向 角を $\beta$ ，とすると $v_{0}$ の $s_{1}, s_{2}$ 成分 $u_{1}{ }^{0}, u_{2}{ }^{0}$ は

$$
u_{i}{ }^{0}=v_{0} \cos (\theta-\beta-\phi) / \cos \phi, \quad u_{2}{ }^{0}=v_{0} \sin (\beta-\theta) / \cos \phi
$$

である。iii) より $r=0$ で $u_{1}{ }^{0}+\sin \phi u_{2}{ }^{0}=f(\theta)$ だから結局

$$
f(\theta)=v_{0} \cos (\theta-\beta)
$$

vi）学iv), v) 飞戻して

$$
\left.\begin{array}{l}
u_{1}=\frac{v_{0}}{\cos \phi} \cos (\beta+\phi-\theta)-v_{0} \mu e^{\mu\left(\theta-0_{0}\right)} \sin \left(\theta_{0}-\beta\right)-\sin \phi \cdot g(r) e^{\mu \theta} \\
u_{2}=\frac{v_{0}}{\cos \phi} \sin (\beta-\theta)+\frac{v_{0}}{\cos \phi} e^{\mu\left(\theta-\theta_{0}\right)} \sin \left(\theta_{0}-\beta\right)+g(\boldsymbol{r}) e^{\mu \theta}
\end{array}\right\}
$$

$\theta=0_{0}$ での $u_{1}$ か $u_{2}$ が指定されれば $g(\boldsymbol{r})$ が決まり, vii) が速度解となる。な扮 $r=0$ では vi), vii）を比

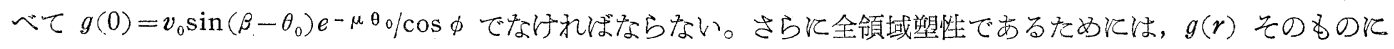
ある制限が課せられるが，これとついて次次節で調べる。

\section{3. 塑性流動における応力とひずみ増分の関係}

物体内で応力值が降伏条件を満たす值澾すれば以後無制限な変位の増大を生ずる。ここで降伏条件は Coulomb-Mohr 式

$$
\psi \equiv\left(\frac{\sigma_{x}-\sigma_{y}}{2}\right)^{2}+\tau_{x y}{ }^{2}-\left(\frac{\sigma_{x}+\sigma_{y}}{2}+c \cot \phi\right){ }^{2} \sin ^{2} \phi=0
$$

である。この流動状態湉ける応力とひずみ増分の関係を規定する式を求めよう。委ず $(2.2)$ 式より， $\theta$ を消去 
乙て

$$
\left.\begin{array}{c}
\left(\dot{\boldsymbol{\varepsilon}}_{x}+\dot{\boldsymbol{\varepsilon}}_{y}\right)^{2}=\left\{\left(\dot{\varepsilon}_{x}-\dot{\varepsilon}_{y}\right)^{2}+4 \dot{r}_{x y^{2}}\right\} \sin ^{2} \phi \\
\text { たは } \frac{\dot{e}^{2}}{\sin ^{2} \phi}=\left(\dot{\boldsymbol{\varepsilon}}_{x}-\dot{e}\right)^{2}+\dot{\gamma}_{x y}{ }^{2}\left(\dot{e}=\frac{\dot{\varepsilon}_{x}+\dot{\varepsilon}_{y}}{2}\right)
\end{array}\right\}
$$

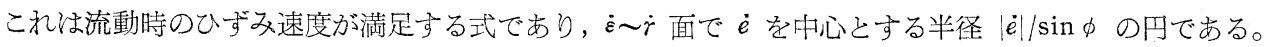

応力とひずみ増分の関係は i) 同時に (3.1) 式と (3.2) 式を満たず゙きとと, ii) 过り線と沿つては $\dot{\varepsilon}_{s}=0$

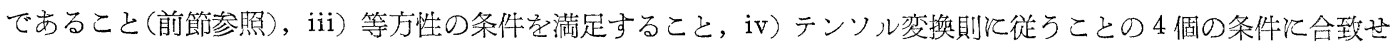
ねばならない。このような関係は

$$
\begin{gathered}
\dot{\varepsilon}_{x}=k\left[\left\{\frac{\cos ^{2} \phi}{2} \sigma_{x}-\left(1-\frac{\cos ^{2} \phi}{2}\right) \sigma_{y}\right\}-\mathrm{c} \sin \phi \cos \phi\right] \\
\dot{\varepsilon}_{y}=k\left[\left\{\frac{\cos ^{2} \phi}{2} \sigma_{y}-\left(1-\frac{\cos ^{2} \phi}{2}\right) \sigma_{x}\right\}-c \sin \phi \cos \phi\right] \\
\dot{r}_{x y}=k \tau_{x y}
\end{gathered}
$$

である。ここに $k$ は比例係数 (スカラー点関数) でその意味は後述する。(3.3) 式より

$$
\dot{\varepsilon}_{x}+\dot{\varepsilon}_{y}=-k\left[\sin ^{2} \phi\left(\sigma_{x}+\sigma_{y}\right)+2 c \sin \phi \cos \phi_{\lrcorner}, \quad \dot{\varepsilon}_{x}-\dot{\varepsilon}_{y}=k\left(\sigma_{x}-\sigma_{y}\right)\right.
$$

であるから，これらを(3.2) 式代代入すると (3.1) 式が得られる (条件 $\mathrm{i}$ )。次に $y$ 方向を过り線と考光ると Mohr 円の考光から

$$
\sigma_{y}=\sigma_{x}\left(1+2 \tan ^{2} \phi\right)+2 c \tan \phi
$$

であるが，これを(3.3) 式に用いると容易に $\dot{\boldsymbol{\varepsilon}}_{y}=0$ が験められる（性質 ii))。また (3.3) 式の第三式性等方性 を示すととにほかならな。さらに (3.3) 式の関係式は (3.1) 式の $\psi$ と

$$
\dot{\varepsilon}_{x}=k \partial \psi / \partial \sigma_{x}, \quad \dot{\varepsilon}_{y}=k \partial \psi / \partial \sigma_{y}, \quad 2 \dot{\gamma}_{x y}=k \partial \psi / \partial \tau_{x y}
$$

で結ばれることが注目されるべきである。恃不変量として応力テンソルのスカラー関数であるから，その成分

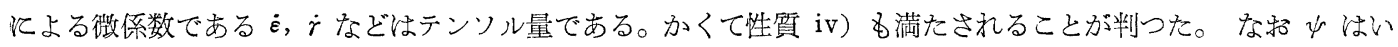
わゆる塑性ポテンシアルK相当するるのである。(3.3) 式を主軸表示に改めると

$$
\dot{\varepsilon}_{i}=k\left[\left\{\frac{\cos ^{2} \phi}{2} \sigma_{i}-\left(1-\frac{\cos ^{2} \phi}{2}\right) \sigma_{j}\right\}-c \sin \phi \cos \phi\right] \quad(i, j=1,2)
$$

以上を拡張して三次元に括ける応力とひずみ速度の関係式を得るため

$$
\dot{\varepsilon}_{i}=K\left[\sigma_{i}-\nu\left(\sigma_{j}+\sigma_{k}\right)+p\right] \quad(i, j, k=1,2,3)
$$

と仮定する。ここに $k, \nu, p$ ほ未定であるが，平面ひずみ問題の場合 (3.6) 式が，(3.5) 式と一致することより 定める。すなわち $\dot{\varepsilon}_{3}=0$ より $\sigma_{3}=\nu\left(\sigma_{1}+\sigma_{2}\right)-p$ となるが，これを(3.6) 式の第一式に入れ

$$
\dot{\varepsilon}_{1}=K\left[\left(1-\nu^{2}\right) \sigma_{1}-\nu(1-\nu) \sigma_{2}+(1+\nu) p\right]
$$

これと(3.5) 式の第一式を比べると

$$
\begin{gathered}
\nu=1-\frac{\cos ^{2} \phi}{2}, K=\frac{2 k}{4-\cos ^{2} \phi}, p=-c \sin \phi \cos \phi \\
\therefore \quad \dot{\varepsilon}_{i}=\frac{2 k}{4-\cos ^{2} \phi}\left[\sigma_{i}-\left(1-\frac{\cos ^{2} \phi}{2}\right)\left(\sigma_{j}+\sigma_{k}\right)-c \sin \phi \cos \phi\right](i, j, k=1,2,3)
\end{gathered}
$$

が得られる。これが求める三次元への搪張式であるが，ポアソン比当るレが $1 / 2$ より小さくないととが注目さ れることである (次節参照)。ひずみ速度の三個の主成分 $\dot{\varepsilon}_{i}$ が二次元と同じく, あるスカラ一関数 $\Psi$ の応力成分

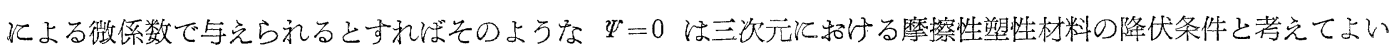
と思われる。

$$
\Psi=\left(\frac{1}{6}+\frac{\sin ^{2} \phi}{18}\right)\left[\left(\sigma_{1}-\sigma_{2}\right)^{2}+\left(\sigma_{2}-\sigma_{3}\right)^{2}+\left(\sigma_{3}-\sigma_{1}\right)^{2}\right]-\left(\frac{\sigma_{1}+\sigma_{2}+\sigma_{3}}{3}+\cot \phi\right) \sin ^{2} \phi=0
$$

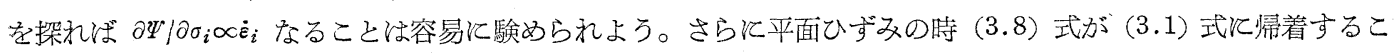
との検証も簡単である。上式で $\phi=0$ とすれば

$$
\Psi_{0}=\left(\sigma_{1}-\sigma_{2}\right)^{2}+\left(\sigma_{2}-\sigma_{3}\right)^{2}+\left(\sigma_{3}-\sigma_{1}\right)^{2}-6 c^{2}=0
$$

でこれは Mises の降伏条件にほかならない。(3.8) 式を星埜教授 ${ }^{5}$ の塑性理論による降状条件と対比してみよ う。同論文で用いている平均圧応力 $\sigma_{m}$ 之，八面体せん断応力 $\tau_{m}$ ならびと降伏条件は

$$
\left.\begin{array}{l}
\frac{1}{3}\left(\sigma_{1}+\sigma_{2}+\sigma_{3}\right)+c \cot \phi=\sigma_{m}, \quad \sqrt{\left(\sigma_{1}-\sigma_{2}\right)^{2}+\left(\sigma_{2}-\sigma_{3}\right)^{2}+\left(\sigma_{3}-\sigma_{1}\right)^{2}}=3 \tau_{m} \\
\tau_{m}=\tan \psi \cdot \sigma_{m}, \\
\sin \phi=\frac{3 \tan \psi}{2 \sqrt{2} \sqrt{1-\kappa+\kappa^{2}}+(1-2 \kappa) \tan \psi}
\end{array}\right\}
$$




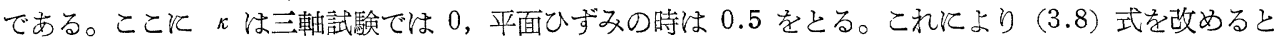

$$
\tau_{m}=\sigma_{m} \cdot \sqrt{2} \sin \phi / \sqrt{3+\sin ^{2} \phi} \quad \therefore \sqrt{2} \sin \phi / \sqrt{3+\sin ^{2} \phi} \sim \tan \psi
$$

本理論の当否は (3.9) 式の両辺の值の比較によりある程度は果されると思われるがその結果を表一1 と掲げる。

表一1

\begin{tabular}{c|c|c|c|c|c|c|c|c|c}
\hline$\phi$ (度) & 0 & 5 & 10 & 15 & 20 & 25 & 30 & 35 & 40 \\
\hline$\sqrt{2} \sin \phi / \sqrt{3+\sin ^{2} \phi}$ & 0 & 0.712 & 0.142 & 0.209 & 0.274 & 0.334 & 0.393 & 0.444 & 0.492 \\
\hline $\tan \psi=\sqrt{2} \sin \phi \sqrt{3}$ (平面ひずみ) & 0 & 0.712 & 0.142 & 0.212 & 0.279 & 0.345 & 0.408 & 0.469 & 0.525 \\
\hline $\tan \psi=\frac{2 \sqrt{2} \sin \phi}{3-\sin \phi}$ (三軸圧縮) & 0 & 0.082 & 0.167 & 0.250 & 0.333 & 0.423 & 0.514 & 0.606 & 0.703 \\
\hline
\end{tabular}

平面問題と猢る (3.9) 式の両值の一致怙相当よいが，これは (3.8) 式が二次元での考察から出発して得られ たものであるため当然ともい方る。これと反して三次元軸対称では $\phi$ の大きところでね差が大になり, $\phi=40^{\circ}$ では約 30\% のくい違いが見られる。

(3.3) 式以下の式に現われた $k$ は常数でない。三次元の場合はむしろ見易いから二次元式によつてその物理的 意味を調べる。平面ひずみでは全塑性仕事率 $(\dot{W})$, 容積仕事率 $\left(\dot{W}_{v}\right)$, 形状変形仕事率 $\left(\dot{W}_{s}\right)$ が次式を満足する。

$$
\dot{W}_{s}=\dot{W}-\dot{W}_{v}=\sigma_{1} \dot{\varepsilon}_{1}+\sigma_{2} \dot{\varepsilon}_{2}-\frac{1}{3}\left(\sigma_{1}+\sigma_{2}+\sigma_{3}\right)\left(\dot{\varepsilon}_{1}+\dot{\varepsilon}_{2}\right)
$$

(3.7) 式の第三式より $\dot{\boldsymbol{\varepsilon}}_{3}=0$ の時

$$
\left.\begin{array}{l}
\sigma_{3}=\frac{1+\sin ^{2} \phi}{2}\left(\sigma_{1}+\sigma_{2}\right)+c \sin \phi \cos \phi=\frac{1}{2}\left(\sigma_{1}+\sigma_{2}\right)+\frac{3}{2} \delta \\
\delta=\frac{2}{3}\left[\left(\sigma_{1}+\sigma_{2}\right) \frac{\sin ^{2} \phi}{2}+c \sin \phi \cos \phi\right]=\frac{1}{3}\left(\sigma_{1}-\sigma_{2}\right) \sin \phi\left(\sigma_{1}>\sigma_{2}\right)
\end{array}\right\}
$$

上の第二式は (3.1) 式を用いて改めた。これを(3.10) 式へ代入し (3.5) 式を用いると

$$
\dot{W}_{s}=\frac{k\left(\sigma_{1}-\sigma_{2}\right)^{2}}{6}\left(3+\sin ^{2} \phi\right)
$$

$$
\therefore \quad k=\frac{6 \dot{W}_{s}}{\left(3+\sin ^{2} \phi\right)\left(\sigma_{1}-\sigma_{2}\right)^{2}}=\frac{6 \dot{W}_{s}}{\left(3+\sin ^{2} \phi\right)\left\{\left(\sigma_{1}+\sigma_{2}\right) \sin \phi+2 c \cos \phi\right\}^{2}}
$$

が得られる。このように $k$ はスカラー関数で, 形状変形仕事率に比例し, 平均圧応力の增大にともなつて小さく なる。換言すれば内圧が大きくなれば塑性ひずみ速度，またはその増分が内圧の逆比的飞制約されることになる。 三次元に対しては (3.11) 式の分母が $\left(3+\sin ^{2} \phi\right) \cdot\left(\sigma_{1}-\sigma_{2}\right)^{2}$ の代りに $2\left\{\left(\sigma_{1}-\sigma_{2}\right)^{2}+\left(\sigma_{2}-\sigma_{3}\right)^{2}+\left(\sigma_{3}-\sigma_{1}\right)^{2}\right\}$ にる。

(3.5), (3.7) 式はともと偏差テンソルにより

$$
\left.\begin{array}{c}
\dot{\varepsilon}_{i}=k \sigma_{i}{ }^{\prime} \quad(i=1,2 \text { または } 1,2,3) \\
\text { ただし } \quad \dot{\varepsilon}_{i}{ }^{\prime}=\dot{\varepsilon}_{i}-\frac{\dot{\varepsilon}_{1}+\dot{\varepsilon}_{2}+\dot{\varepsilon}_{3}}{3}, \quad \sigma_{i}{ }^{\prime}=\sigma_{i}-\frac{\sigma_{1}+\sigma_{2}+\sigma_{3}}{3}
\end{array}\right\}
$$

と表わすことができる。すなわち摩擦がある時でも，応力とひずみ速度の偏差成分は金属の剛塑性枋ける LévyMises の関係式と同型となることが判る。

今までは剛塑性域での応力とひずみ速度の関係を考えてきたが，弾性ひずみの存在が無視できない時は (3.7)式 を拡張して全ひずみ速度が Prandtl-Reuss 式より類推して

$$
\dot{\varepsilon}_{i}=\frac{2 k}{4-\cos ^{2} \phi}\left[\sigma_{i}-\left(1-\frac{\cos ^{2} \phi}{2}\right)\left(\sigma_{j}+\sigma_{k}\right)-c \sin \phi \cos \phi\right]+\frac{1}{E}\left[\dot{\sigma}_{i}-\nu_{e}\left(\dot{\sigma}_{j}+\dot{\sigma}_{k}\right)\right](i, j, k=1,2,3) \cdots
$$

と表わせる。ここに $E, \nu_{e}$ は弾性域での綐弾性率およびポアソン比である。上式の右辺第二項は弾性ひずみ速度 $\dot{\boldsymbol{\varepsilon}}_{i}{ }^{e}$ であるので $\dot{\boldsymbol{\varepsilon}}_{i}{ }^{p}=\dot{\boldsymbol{\varepsilon}}_{i}-\dot{\boldsymbol{\varepsilon}}_{i}{ }^{e}$ は純塑性ひずみ速度である。したがつて (3.11) 式を導いたと全く同様代 $k=3 \dot{W}_{s}^{p} /\left\{\left(\sigma_{1}-\sigma_{2}\right)^{2}+\cdots\right\}$ である。一般なる軸について (3.13) 式にテンソル変換を施せぼ $G$ を弾性せ九断剛性 率とする時 $\quad \dot{r}_{x y}=k \tau_{x y}+(1 / 2 G) \dot{\tau}_{x y}$ など

降伏条件を満たさ好応力変化 (例光ば一椂圧縮) を除荷と呼ぶことにすると, 除荷の際は (3.13) 式の代りに $\dot{\boldsymbol{\varepsilon}}_{i}=\dot{\varepsilon}_{i}{ }^{e}=\left[\dot{\sigma}_{i}-\nu_{e}\left(\dot{\sigma}_{j}+\dot{\sigma}_{k}\right)\right] / E$ と考光るべきである(弾性公式)。

な招弾塑性状態での (3.13) 式に応ずる平面ひずみの関係は複雑である(後述の例一2 参照)。

(例一1) 対数螺旋过り線場でのひずみ速度

前例で極座標を用いると $\quad u_{r}=u_{1}+u_{2} \sin \phi=v_{0} \cos (\theta-\beta)$ 


$$
u_{\theta}=u_{2} \cos ^{*} \phi=v_{0} \sin (\beta-\theta)+h(r) \cos \phi e^{\mu \theta}, h(r) \equiv g(r)-g(0)=g(r)-\frac{v_{0} e^{-\mu \theta_{0} \sin \left(\beta-\theta_{0}\right)}}{\cos \phi}
$$

であるので

$$
\dot{\varepsilon}_{r}=\frac{\partial u_{r}}{\partial r}, \quad \dot{\varepsilon}_{\theta}=\frac{\partial u_{\theta}}{r \partial \theta}+\frac{u_{r}}{r}, 2 \dot{r}_{r} \theta=\frac{\partial u_{r}}{r \partial \theta}+\frac{\partial u_{\theta}}{\partial r}-\frac{u_{\theta}}{r}
$$

竌入れて

$$
\dot{\varepsilon}_{r}=0, \dot{\varepsilon}_{\theta}=\mu \frac{h(r)}{r} \cos \phi e^{\mu \theta}, 2 \dot{\gamma}_{r \theta}=\left(\frac{d h}{d r}-\frac{h}{r}\right) \cos \phi e^{\mu \theta}
$$

このひずみ速度成分は (3.2)式，または変換して得られる

$$
\left(\dot{\varepsilon}_{r}+\dot{\varepsilon}_{\theta}\right)^{2}=\left\{\left(\dot{\varepsilon}_{r}-\dot{\varepsilon}_{\theta}\right)^{2}+4 \dot{r}_{r} \theta^{2}\right\} \sin ^{2} \phi
$$

艺満足せねばならない（全域塑性の仮定）。ii）に i）を代入して

$$
\begin{aligned}
& \frac{d h}{d r}=\frac{2 h}{r} \quad \therefore h=c r^{2}(c \text { 瑺数 }) \\
& \therefore g(r)=\frac{v_{0} e^{-\mu \theta_{0} \sin \left(\beta-\theta_{0}\right)}}{\cos \phi}\left\{1-\left(\frac{r}{\rho}\right)^{2}\right\}
\end{aligned}
$$

のような解が得られる。ただし $\theta=\theta_{0}$ 上で $g(\rho)=0$ とする。

(例一2) 平面ひずみ条件での圧縮 ${ }^{1)}$

弾塑性の問題の一例として, $x$ 方向が自由, $z$ 方向が剛性拘束， $y$ 方向飞圧縮する問題を取り扱う。

(3.13) 项住

$$
\left.\begin{array}{l}
d \varepsilon_{y} \sim d \varepsilon_{2}=\left\{\sigma_{2}-\nu\left(\sigma_{3}+\sigma_{1}\right)-c \sin \phi \cos \phi\right\} d \lambda+\frac{1}{E}\left\{d \sigma_{2}-\nu\left(d \sigma_{3}+d \sigma_{1}\right)\right\} \\
d \varepsilon_{z} \sim d \varepsilon_{3}=\left\{\sigma_{3}-\nu\left(\sigma_{1}+\sigma_{2}\right)-c \sin \phi \cos \phi\right\} d \lambda+\frac{1}{E}\left\{d \sigma_{3}-\nu_{e}\left(d \sigma_{1}+d \sigma_{2}\right)\right\}
\end{array}\right\}
$$

ただし $\nu=\left(1+\sin ^{2} \phi\right) / 2, \quad \sigma_{1}=0, d \varepsilon_{3}=0$ として上の二式から $d \lambda$ を消去すると

$$
E d \varepsilon_{2}=-\frac{\sigma_{2}-\nu \sigma_{3}-c \sin \phi \cos \phi}{\sigma_{3}-\nu \sigma_{2}-c \sin \phi \cos \phi} \cdot\left(d \sigma_{3}-\nu_{e} d \sigma_{2}\right)+d \sigma_{2}-\nu_{e} d \sigma_{3}
$$

a) 降伏条件として (3.8) 式を用いると $\sigma_{1}=0$ だから

$$
\left(\frac{1}{3}+\frac{\sin ^{2} \phi}{9}\right)\left(\sigma_{2}^{2}+\sigma_{3}^{2}-\sigma_{2} \sigma_{3}\right)=\left(\frac{\sigma_{2}+\sigma_{3}}{3}+c \cot \phi\right)^{2} \sin ^{2} \phi
$$

これを微分して

$$
d \sigma_{2}\left(\sigma_{2}-\nu \sigma_{3}-c \sin \phi \cos \phi\right)+d \sigma_{3}\left(\sigma_{3}-\nu \sigma_{2}-c \sin \phi \cos \phi\right)=0
$$

iii), iv) より $\sigma_{3}, d \sigma_{3}$ を求めて ii) 飞入れて積分すると

$$
\begin{aligned}
E \varepsilon_{2} & =\sigma_{2}\left\{1-\frac{\left(1-\sin ^{2} \phi\right)^{2}}{2}-\nu_{e}\left(1+\sin ^{2} \phi\right)\right\}-\frac{\cos \phi \sqrt{3+\sin ^{2} \phi}}{2}\left\{-2 \nu_{e}+\left(1+\sin ^{2} \phi\right)\right\} \\
& \times \sqrt{4 c^{2}+4 \sigma_{2} \tan \phi-\sigma_{2}^{2}}-c \cos \phi \frac{3+\sin ^{2} \phi}{2} \tanh ^{-1}\left(\frac{2 c \tan \phi-\sigma_{2}}{2 c} \cos \phi\right)+C^{\prime}
\end{aligned}
$$

$C^{\prime}$ は降伏開始時の $\sigma_{2}$ を $\sigma_{2}{ }^{0}$ とすると, その時 $\varepsilon_{2}=\varepsilon_{2}{ }^{0}$ (降伏開始または弾性上限でのひずみ)であることか 占決る。ここに $\sigma_{2}{ }^{0}, \varepsilon_{2}{ }^{0}$ は Hooke の法則と降伏条件 iii) より

$$
\sigma_{2}{ }^{0} / c=\frac{3 \cos \phi}{\sqrt{\left(3+\sin ^{2} \phi\right)\left(\nu_{e}{ }^{2}-\nu_{e}+1\right)}-\left(1+\nu_{e}\right) \sin \phi} E \varepsilon_{2}{ }^{0} / c=\sigma_{2}{ }^{0} / c\left(1-\nu_{e}{ }^{2}\right)
$$

図-3

で与觉られることねただちに解る。

$\sigma_{2}{ }^{0}$ は $\phi=0 \nu_{e}=0.5$ の時は $2 c$ であり $\phi$ とと 尼飞増大する。 $\tanh ^{-1}$ 内の引擞が $(-1)$ 近づ く時 $\varepsilon_{2} \rightarrow \infty$ となる。

夺なわち $\sigma_{2} \rightarrow 2 c \cos \phi /(1-\sin \phi) \equiv \sigma_{2}, Y$ で無制 限流動が起こる。な招 $\sigma_{2}, Y$ は $2 c \tan (\pi / 4+\phi / 2)$ だから一軸圧縮強度の意味をるつ。 $\nu_{e}=0.3$ 亿つ 心て $\sigma_{2} / c$ と $E \varepsilon_{2} / c$ の関係を 図一 3 亿示卞。

b) (3.1) 式を用いる時子類似の結論が得られ る。ただし (3.1) 式には $\sigma_{z}\left(\right.$ また $\sigma_{3}$ )を含ま ないから i) は $\varepsilon_{2}$ と $\sigma_{3}$ の関係を与光るのに役 立つ。流動開始直前の弾性ひずみを $\varepsilon_{2}{ }^{e}$ とすると (v) の代り淡

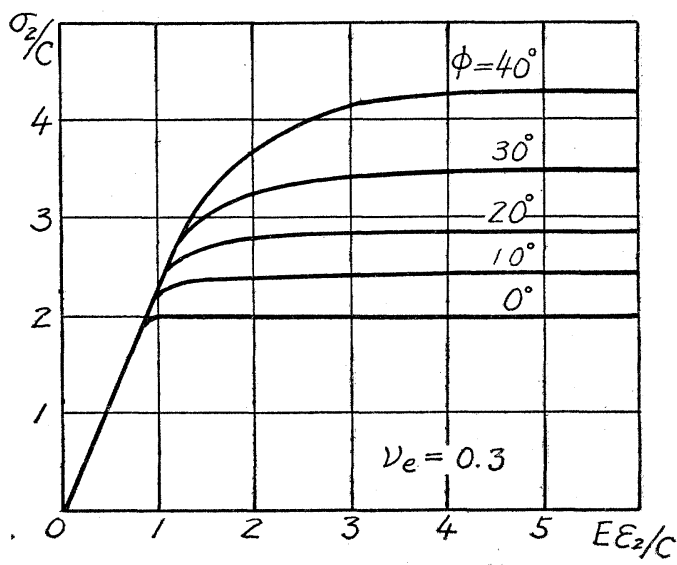


$E\left(\varepsilon_{2}-\varepsilon_{2}^{e}\right)=\left(1-\frac{\cos ^{2} \phi}{2}-\nu_{e}\right)\left(\sigma_{3}-\frac{2 \nu_{e} c \cos \phi}{1-\sin \phi}\right)+c \cos \phi \frac{3+\sin ^{2} \phi}{2} \log \left(\frac{c-\frac{2 \nu_{e} c}{1+\sin \phi}}{c-\frac{1-\sin \phi}{\cos \phi(1+\sin \phi)} \sigma_{3}}\right)$

(3.1) 式より $\sigma_{2}=\sigma_{2, Y}$ の時流動が起こるが, その時 vii）より

$$
\sigma_{3} \rightarrow \frac{c(1+\sin \phi) \cos \phi}{1-\sin \phi}=\frac{\sigma_{2}, Y}{2}(1+\sin \phi)<\sigma_{2}, Y
$$

で流動時の拘束圧が求まる。これは中間主応力 $\left(\sigma_{2}>\sigma_{3}>\sigma_{1}\right)$ である。

\section{4. ダイレイタンシーへの応用}

前節で求めたポアソン比 $\nu\left(=\frac{1}{2}\left(1+\sin ^{2} \phi\right)\right)$ が $1 / 2$ より大きいことは，一般粒状物質が塑性流動を起こす ときとの容積が膨脤することを意味する。これはダイレイタンシーととし知られている。星杽教授 ${ }^{5)}$ の理論に招 いて一軸圧縮の場合の降伏時のポアソン比は $\nu_{f}=1 /\left(2-\sin ^{2} \psi\right)$ で与光られている。表一2 2 と $\nu_{f}$ の対比を 平面ひずみと軸対称の雨者について行つたるのである。

表-2

\begin{tabular}{c|c|c|c|c|c|c|c|c|c}
\hline$\phi$ (度) & 0 & 5 & 10 & 15 & 20 & 25 & 30 & 35 & 40 \\
\hline$\nu$ & 0.500 & 0.504 & 0.515 & 0.532 & 0.558 & 0.590 & 0.625 & 0.665 & 0.707 \\
\hline$\nu_{f}$ (平面ひずみ: $\left.\tan \psi=\sqrt{2} \sin \phi / \sqrt{3}\right)$ & 0.500 & 0.504 & 0.516 & 0.534 & 0.561 & 0.595 & 0.637 & 0.685 & 0.760 \\
\hline$\nu_{f}$ (軸対称: $\tan \psi=2 v \overline{2} \sin \phi /(3-\sin \phi)$ & 0.500 & 0.502 & 0.521 & 0.550 & 0.588 & 0.605 & 0.730 & 0.839 & 0.992 \\
\hline
\end{tabular}

この場合も申が大きくなると軸対称でことに両者の差は大きくなり， $\phi=40^{\circ}$ での請差は約 $30 \%$ であるが，全 域にわたる一致の程度は前掲表一1より良好である。三軸試験に招けるせん断時の容積変化は初めはわずが収縮 するがやがて膨脹に転じ降伏して軸応力が增大せ㰠うになつてるな膨脹を続けるが, その程度は漸次小となり

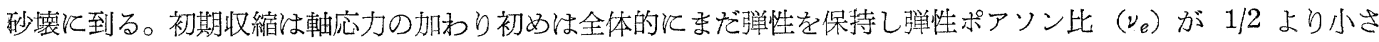
いことに原因すると思われる。塑性域の拡大にとるなつて膨脹が起こるが，降伏点を過ぎると全体としてゆるみ始 め $\phi$ が減少する。したがつてポアソン比は再び $1 / 2$ そ近づき非圧縮的となつて膨脹率が減少するものと考完ら れる。また砂の場合密詰めである程 $\phi$ も大きく同時膨脹率も大きいがこれは $\nu=\frac{1}{2}\left(1+\sin ^{2} \phi\right)$ が $\phi$ と共に大 きくなることによるのであろう。このようと本文で導いたポアソン比は土のせん断時の容積変化を定性的に説明 乙得るのであるが, 定量的吟味を行うために直接せん断と三軸圧縮に捛ける砂質土 $(c=0)$ の流動時の容積変化を 表わす式を求めよう。二次元では (3.3) 式汸いて $\tau_{x y}=\tau_{s}=\left(\sigma_{1}+\sigma_{2}\right) \sin \phi \cos \phi / 2$ を考光ると単位膨脹率 $\dot{v}$ が

で与壳らる。

$$
-\left(\dot{\varepsilon}_{x}+\dot{\varepsilon}_{y}\right) \equiv \dot{v}=k \sin ^{2} \phi\left(\sigma_{1}+\sigma_{2}\right)=\frac{\dot{\gamma}_{s}}{\tau_{s}} \sin ^{2} \phi\left(\sigma_{1}+\sigma_{2}\right)=2 \dot{\gamma}_{s} \tan \phi
$$

流動変形時の $\phi$ の変化を無視すれば上式を積分し $v=2 \gamma_{s} \tan \phi$ となるが，これより容積変化はせん断ひずみ 飞, 比例し（したがつて直接せん断ならほぼ水平変位に比例）平均圧力 (直接せん断ではほぼ上下圧)には無関係 でかつめの大きい程大きい。このことは図一4亿示す笑験 結果と照しても妥当のようである。本実験は砂質ロームを 粒径が $0.11 〜 0.4 \mathrm{~mm}$ であるごとくふるい分けしたるの を $10 \%$ の含水比で単位重量 $\left(W_{t}\right)$ が 2.0 招よび 1.75 $\mathrm{gr} / \mathrm{cm}^{3}$ であるように圧縮機で静的に締固めた試料につ いて一面せん断を行つたものである。横軸は降伏笼の水平 変位で縦軸は鉛直上昇高を試料厚 (一定で $h_{0}=3.56 \mathrm{~cm}$ ) で割つたものである。試験は上下圧を 4 種变えて沶の拉 の3回行つたものの平均を図示したが, 膨脹（

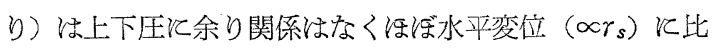
列して特り，かつ $W_{t}$ が大きいとき（したがつてめも大） の膨脹注 $W_{t}$ の小いときに比べて大となり前式の特性に 違背しない。直接せ九断では流動域がせん断面をはさむ薄

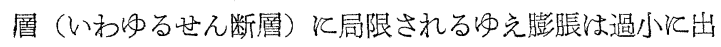

図-4

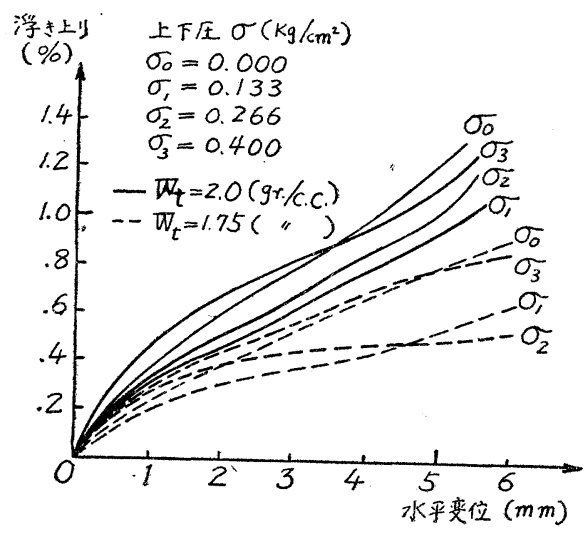


るであろう。 $\gamma_{s}$ の概略の推定値として（水平変位/試料径）を以てすれば浮き上りの実験值は (4.1) 式より求め る $v$ の約 15 分の 1 である。これより逆算してせん断首の厚さは $h_{0} / 15 \div 2.5 \mathrm{~mm}$ 程度と推定される。

三軸試験と扮けるダイレイタンシー式は $\sigma_{1}$ を軸応力， $\sigma_{2}=\sigma_{3}$ を側圧とすると (3.7) 式より

だから

$$
\dot{\varepsilon}_{1}=K\left[\sigma_{1}-\left(1+\sin ^{2} \phi\right) \sigma_{2}\right], \dot{\varepsilon}_{2}=\dot{\varepsilon}_{3}=K\left[\sigma_{2}-\frac{1}{2}\left(1+\sin ^{2} \phi\right)\left(\sigma_{1}+\sigma_{2}\right)\right]
$$

$$
-\left(\dot{\varepsilon}_{1}+\dot{\varepsilon}_{2}+\dot{\varepsilon}_{3}\right)=\dot{v}=\dot{\varepsilon}_{1} \frac{\sin ^{2} \phi\left(\sigma_{1} / \sigma_{2}+2\right)}{\sigma_{1} / \sigma_{2}-\left(1+\sin ^{2} \phi\right)} \cdots
$$

のようとなる。ただし円筒供試体の全域塑性を仮定し ている。 $\sin \phi$ は $\left(\sigma_{1}-\sigma_{2}\right) /\left(\sigma_{1}+\sigma_{2}\right)=\sin \phi$ で与兄ら れるとしてよいから流動時の膨脹は試験時の $\sigma_{1} / \sigma_{2}$ 之 $\varepsilon_{1}$ 図表が知れる時 (4.2) 式を図式皇をは数值積分す ることにより評価できる。

図一5 にはこのように求めた $v$ の計算值と実験值 を示す。この実験值は口印は Taylor ${ }^{6)}$ の書にあるも の，それ以外は鉛散弾につき Newland-Allery ${ }^{7)}$ の行 つた実験の值を引用した。試料は相当密な状態のるの

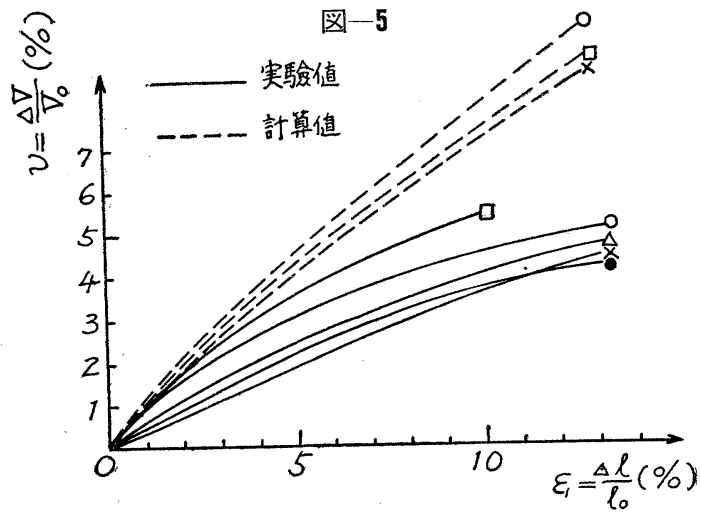
であるがこの時の理論との差は約 1.5 倍程度計算值が過大になつている。この理由として考兄られることは三軸 試験でるな扮試料全体に対する塑性域の拡大はあり得ないからであろう。事実両端面での拘束により試料内に円 錐形の剛性域が発達するから長径比 2 の寸度では全容積の $2 / 3$ 程度が高々塑性域となり得る飞過ぎない。図一5 の計算値の $2 / 3$ がほぼ実測值の平均を通ることはこれを裏書きしているとい兄う。

しかしながら一般にゆる詰めの場合 (4.2) 式は $\phi$ が小になれば減少するが，その程度があまり大きくないの で計算值は実験值に比べずつと過大になる（約 4 5 倍)。これは理論の仮定がゆる詰めにはあ⿱り適用しがたい こと（ゆる詰めでは明確な降伏点がなく完全塑性の仮定が良い近似でなくなる）飞るよるのであるう。またゆる 詰めの際はせん断層が十分発達せ奴中破壊が進むとも考学られるがこれらの理由で計算值が大きく出るのであ ろうと思う。

\section{5. 結 論}

本理論の組み立ては応力と速度の特性曲線が 一致することのみを基礎仮定としているが，導かれた応力とひず み增分の関係, 三次元降伏条件式, 流動時のポアソン比,さらにせん断時の粒状物質の膨脹現象などは従来の理論, 実験と対比し少なく共定性的に，としてある程度定量的にも矛盾がないことが示された。これにょり今まで不明 瞭であつた摩擦性塑性体の流動力学に一つの足掛りが得られたと思う。降伏条件を塑性ポテンシアルとする応力, ひずみ増分の関係式は今後解の一意性等のより基本的な問題の解明飞役立つであろう。

本論文は摩擦性塑性材料関する理論的研究の一部であるが，これに関しては特に 東京大学最上教授より幾多 の御示睃と御教示を仰いだ。ここに記して感謝の意を表したい。

\section{参考 文 献}

1) R. Hill: The Mathematical Theory of Plasticity, p.299,p.77

2) T. Mogami: On the Law of Friction of Sand, 2nd. I.C.S.M.F.E.

3) B. Hansen: General Plasticity Theory of Clay, Géotechnique (1952).

4) W. Prager \& P.G. Hodge: Theory of Perfectly Plastic Solids, p.146.

5) 星埜 和：土の力学に㧍ける塑性の基本理論と三軸試験への適用，土木学会論文集 第 21 号 (1954)

6) D.W. Taylor: Fundamentals of Soil Mechanics, p. 335

7) P.L. Newland \& B.H. Allely: Volume Changes in Drained Triaxial Tests on Granular Materials. Géotechnique, (1955).

(昭.33.9.12) 